\title{
of Law and Religion
}

Volume XVIII

Number 2

2002-2003

\section{Articles}

Faith and Law in a Multicultural World (James Luther Adams Lecture, Emory University, February 6, 2002)

Harold J. Berman

An Introduction to Bahā'ì Law: Doctrinal Foundations, Principles and Structures

Udo Schaefer

Healing at the Borderland of Medicine and Religion: Regulating Potential Abuse of Authority by Spiritual Healers

Michael H. Cohen

All You Need is Love: Paul Ramsey's Basic Christian Ethics and the Dilemma of Protestant Antilegalism

Robert W. Tuttle

No Other Gods: Answering the Call of Faith in the Practice of Law

Howard Lesnick

\section{Book Review}

Separation of Church and State, by Philip Hamburger
Timothy L. Hall 
Sponsored by: Hamline University School of Law

Published by: Hamline University School of Law ISSN: 0748-0814 


\title{
THE JOURNAL OF LAW AND RELIGION
}

\author{
EDITORIAL STAFF
}

Editor

MARIE A. FAILINGER, Hamline University School of Law

Associate Editors

PATRICK KEIFERT, Luther Theological Seminary HOWARD J. VOGEL, Hamline University School of Law

Book Review Editor

STEVEN D. SMITH, San Diego School of Law

Technical Editor

STEPHEN LIEBO, Hamline University School of Law

\section{Production/Subscription Manager LINDA BERGLIN}

JAMES AUSTAD EDITORIAL ASSISTANTS RYAN KATZ

\section{EDITORIAL BOARD}

ELIZABETH MENSCH, State University of New York at Buffalo, School of Law, Chair AZIZAH AL-HIBR, T.C. Williams School of Law, University of Richmond

STEPHEN L. CARTER, Yale Law School ANTHONY COOK, Georgetown University Law Center MARIE FAILINGER, Hamline University School of Law Ex Officio

JON M. GARON, Hamline University School of Law

EMILY ALBRINK HARTIGAN, Saint Mary's University of San Antonio School of Law AFRA JALABI, Writer, Montreal, Quebec JOSÉ ROBERTO JUAREZ, St. Mary's Law School PATRICK R. KEIFERT, Luther Theological Seminary HOWARD LESNICK, University of Pennsylvania Law School NANCY MILLER-HERRON, Attorney at Law, Dresden, Tennessee, Secretary THOMAS PORTER, JUSTPEACE Center for Mediation \& Conflict Transformation EARL SCHWARTZ, Hamline University STEVEN D. SMITH, San Diego School of Law Ex Officio 
DOUGLAS STURM, Professor Emeritus, Bucknell University HOWARD J. VOGEL, Hamline University School of Law, Treasurer 


\section{ADVISORY COMMITTEE}

MILTON KONVITZ, Professor Emeritus, Cornell University of New York, Co-chair DOUGLAS STURM, Professor Emeritus, Bucknell University, Co-chair

TAHA JABER AL-ALWANI, Graduate School of Social and Islamic Sciences

ZAFAR ISHAQ ANSAR, The International Institute of Islamic Thought, Pakistan MOHAMED S. EL-AWA, Cairo, Egypt

RICHARD BAEPLER, Valparaiso University School of Law MILNER BALL, University of Georgia School of Law HAROLD BERMAN, Emory University School of Law GERARD BRADLEY, Notre Dame University Law School JAMES BRESNAHAN, Boston College MICHAEL BROYDE, Emory University School of Law LYNN BUZZARD, Campbell University School of Law FRED CARNEY, Perkins School of Theology, Southern Methodist University MOHAMED S. EL-AWA, Islamic Scholar, Cairo, Egypt

CARL ESBECK, University of Missouri-Columbia School of Law EDWARD MCGLYNN GAFFNEY, JR., Valparaiso University RICHARD HIERS, University of Florida M. CATHLEEN KAVENY, Notre Dame University Law School DAMIEN KEOWN, University of London, Goldsmiths SANFORD LEVINSON, University of Texas School of Law DAVID LITTLE, Harvard University Divinity School ROBIN LOVIN, Perkins School of Theology, Southern Methodist University SEYYED HUSSEIN NASR, George Washington University LOUIS NEWMAN, Carleton College

KAY PRANIS, ST. PAUL, MN

MICHAEL SCHERSCHLJGT, Hamline University School of Law ELISABETH SCHOSSLER FIORENZA, Harvard University Divinity School

THOMAS SHAFFER, Notre Dame University Law School

PETER N. THOMPSON, Hamline University School of Law CHARLES VILLA-VICENCIO, University of Cape Town, South Africa ROSALIE WAHL, Associate Justice, Retired, Minnesota Supreme Court MICHAEL WELKER, University of Heidelberg, Germany JOHN WITTE, Jr., Emory University School of Law WILSON YATES, United Theological Seminary of the Twin Cities Stephen B. Young, Attorney at Law, Saint Paul, Minnesota 
The Journal of Law and Religion is sponsored by the Hamline University School of Law and is a interdisciplinary, interfaith academic and professional publication devoted to investigating the interaction of religion and law.

Subscriptions to The Journal of Law and Religion, which is published twice annually, are $\$ 25$ per two-issue volume for individuals, $\$ 35$ for institutions, and $\$ 10$ for students. Add an additional $\$ 10$ for foreign postage. Subscription requests, manuscripts, book reviews, books to be reviewed, and general correspondence should be addressed to:

\author{
The Journal of Law and Religion \\ 1536 Hewitt Avenue \\ Saint Paul, Minnesota 55104 \\ or jlr@gw.hamline.edu
}

Citations generally conform to the Association of Legal Writing Directors' $A L W D$ Citation Manual. Citations to Jewish/Christian Biblical sources conform to the SBL Handbook of Style and the Jewish Law Annual. Unsolicited manuscripts will be retumed only upon request.

Individual and back issues and complete sets of The Journal of Law and Religion may be ordered directly from William S. Hein \& Co., 1285 Main Street, Buffalo, New York 14209.

The views and opinions expressed in The Journal of Law and Religion are those of the authors and do not necessarily reflect the views of the editorial staff, the editorial board, the advisory board, or the sponsors of The Journal of Law and Religion.

Articles are indexed in the Index to Legal Periodicals published by The H.W. Wilson Co. (Bronx, New York), and in the Legal Resource Index available on-line on a variety of computer database services.

Articles are also indexed in Religion Index One: Periodicals; book reviews are indexed in Index to Book Reviews in Religion. Both indexes are published by the American Theological Library Association, Chicago, and are available online through BRS Information Technologies (Latham, New York) and DIALOG Information Services (Palo Alto, California).

Internet access to The Journal of Law and Religion, including an index to past issues, is available at http://www.hamline.edu/jlr

All copyrights are reserved.

Cite as: $18 \mathrm{~J}$ LAW \& RELIG 2 


\section{JOURNAL OF LAW AND RELIGION}

\section{STATEMENT OF PERSPECTIVE}

The Journal of Law and Religion was initiated in 1982 as a collaborative effort of the Council on Religion and Law and the Hamline University School of Law. It was bom of a sense of historical malaise. The modem age with its strong propensity toward the secularization of all areas of life, while not without merit in its liberating effects, nonetheless has its dark side.

We live, some say, in a time of profound historical crisis. Domestically and globally, we confront massive issues which force us to reconsider, in fundamental ways, the shape and quality of our common life. Yet many of the disciplines of thought and practice that should be a rich resource in such a time are found wanting-among them, law and religion. Law, a discipline presumably devoted to the ways of justice, has all too often become a set of complex, technical tools without concem for higher purpose. Religion, presumably given to the all-embracing promises and prescriptions implied in the sense of the sacred, has all too often become privatized and neglectful of our public life.

The Journal of Law and Religion is dedicated to a fundamental reappraisal of the disciplines of law and religion as they impinge on each other, might instruct each other, and taken in their conjunction, might offer a constructive response to the major issues of our times. As such its concerns are sixfold.

Historical The Journal intends to encourage the examination of historical developments, movements, thinkers, and issues to enrich our understanding of how law and religion have, in various ways, been mutually influential.

Theoretical The Journal intends to promote constructive work in religious and legal thought about fundamental theological and jurisprudential questions pertaining to professional practice and the structures of our public life.

Ethical The Journal intends to support explorations into the foundations of ethical judgment and normative critiques of our social life, particularly as they draw upon resources from the life of law and religion.

Global The Journal intends to be encompassing in its reach, seeking out voices from all the religious and legal traditions throughout the world and bringing them into conversations with each other.

Professional The Journal intends to stimulate collaboration between jurists and religious leaders given their respective commitments, as professionals, to the common good of all peoples.

Spiritual The Journal recognizes that human existence is grounded in the spiritual, which is represented in many forms and expressions.

The Journal is thus a forum within which the disciplines of law and religion might together consider with utmost seriousness their joint responsibility for the creation of a civilization of genuine peace and justice. Within the compass of that purpose, the Journal intends to be open-minded and non-prejudicial; it is receptive to submissions from all persuasions and perspectives. 


\section{HAMLINE \\ UNIVER S I T Y \\ SCHOOL OF LAW}

\section{A subscription to the \\ JOURNAL OF LAW AND \\ RELIGION}

Cost per volume (two issues):

$\$ 15.00$ individual (USA)

$\$ 25.00$ individual (foreign)

$\$ 25.00$ institution (USA)

$\$ 35.00$ institution (foreign)

$\$ 10.00$ student

Circulation Manager

Journal of Law and Religion

Hamline University School of Law

1536 Hewitt Avenue

Saint Paul, Minnesota 55104

Payment Enclosed

Please Bill

Name:

Address:

City:

State:

Zip:

Phone:

Fax:

E-Mail: 


\section{HeNDRICKSON PUBLISHERS}

\section{A bestseller in Israel comes to America, revealing profound intersections between religion and law}

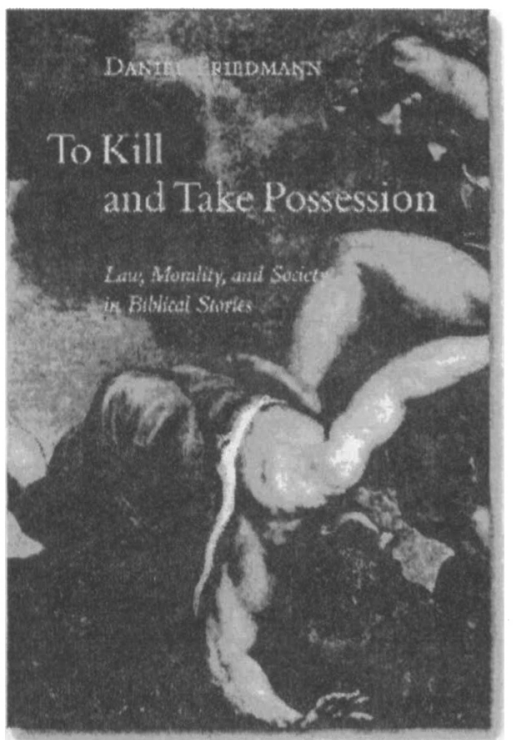

\section{TO KILL AND TAKE POSSESSION}

Law, Morality, and Society in Biblical Stories

DANIEl FriedmanN

Dublished to critical acclaim in Israel and now in America, legal scholar Daniel Friedmann's fascinating book explores the legal, moral, and political aspects of some of the best-known and dramatic stories in the Bible. Friedmann also links biblical approaches to law to events from the past fifty years, such as a 1968 trial in Israel that raised centuries-old issues of religious and political identity through the complex question of "Who is a Jew?" Presenting his arguments with straightforward logic, Friedmann makes a strong case for the continuing relevance of ancient religious and legal attitudes throughout history.

$\$ 29.95$ - ISBN 1-56563-641-4 • cloth -352 pages $6 \times 9 \cdot$ Biblical Interpretation $\bullet$ Ethics

A singularly impressive survey and analysis of well-chosen material for the study of biblical legal culture, a burgeoning topic of inquiry in an increasingly wide range of disciplines. Any person with even a minor interest in biblical legal and ethical issues should find it most stimulating.

\footnotetext{
- Calum Carmichael, Professor Comparative Literature; Adjunct Professor of Law, Cornell University
}

Friedmann ... provid[es] striking insights into the evolution of Jewish law, a wealth of comparative examples from non-Jewish historical and literary sources, and an analysis of the dynamic interrelationship of religion, law, and politics in Jewish history and culture. ... This is a book that deserves a wide readership, not only among lawyers and students of the bible, but among the educated reading public as well.

-STEPHEN WIZner, William O. Douglas Clinical Professor of Law, Yale Law School, and Sackler Professor of Law (Special Appointment), Tel Aviv

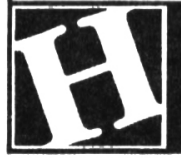




\section{ANNOUNCEMENT}

We have acquired the entire back stock, reprint and microform rights to the

\section{JOURNAL OF LAW AND RELIGION}

\section{Complete sets to date} are now available.

We can also furnish single volumes and issues.

\section{WILLIAM S. HEIN \& COMPANY, INC.}

1285 Main Street

Buffalo, New York 14209 


\section{THE JOURNAL OF LAW AND RELIGION}

VOLUME XVIII

2002-2003
NUMBER 2

\section{TABLE OF CONTENTS}

Editor's Preface

xi

\section{ARTICLES}

Harold J. Berman

Faith and Law in a Multicultural World (James Luther Adams Lecture, Emory

University, February 6, 2002)

Udo Schaefer

An Introduction to Bahā'̄i Law: Doctrinal Foundations, Principles and Structures

Michael H. Cohen

Healing at the Borderland of Medicine and Religion: Regulating Potential Abuse of Authority by Spiritual Healers

Robert W. Tuttle

All You Need is Love: Paul Ramsey's Basic Christian Ethics and the Dilemma of Protestant Antilegalism

Howard Lesnick

No Other Gods: Answering the Call of Faith in the Practice of Law. 459

\section{BOOK REVIEW}

Timothy L. Hall
Separation of Church and State, by Philip Hamburger. 